Historic, Archive Document

Do not assume content reflects current scientific knowledge, policies, or practices. 



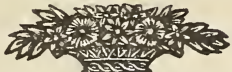

\section{Price List of Fruit Trees}

Prices in this list are for stock delivered at the nursery or packed and delivered at R. R. station, Coon Valley, Wis.

A copy of our descriptive catalog sent free on request 


\section{Early Apples}

Yellow Transparent

Tetofsky 35 cents

Duchess

\section{Early Winter Apples}

\section{Anisim}

Peter

Plum Cider

Snow Apple 35 cents

Patten Greening 20 cents

Delicious 35 cents

Nameless 35 cents

Canada Baldwin 35 cents

Wealthy

\section{Łutumn Apples}

Gideon

Longfield

McMahon

North Star

Wolf River

Iowa Beauty 20 cents
Long Keeping Winter

Apples

Scott Winter

Golden Russet

Northwestern Greening

Tallmans Sweet

Salome 35 cents

Black Anntee

Wallbridge

Grimes Golden

\section{Crab Apples}

Transcendent 35 cents

Hyslop

Whitney

Strawberry

Virginia

Prolific

Martha

Briar Sweet

Florence

Minnesota

PRICE of any variety of Apple and Crab trees listed above: 5 to 7 foot trees 25 cents each excepting where specially priced.

DISCOUNT-10 per cent discount will be allowed on all Apple and $C_{r a b}$ trees on this list excepting on the 20 -cent varieties if you order 25 trees or more,

\section{PLUMS}

Plums are not difficult to grow. and are among the hardiest of our fruits, besides offering the advantage of a large yield of fruit from a small plat of ground, as they can be planted close together.

Cherry Plum-Very hardy, fruit small with cherry flavor, of good quality.

Cheney -Fruit large, sugary. Very productive. Red shaded yellow.
Forest Garden-An ideal plum; very large, early and profuse bearer; rich and sweet.

Surprise-Deep red; excellent quality.

PRICE of above Plum trees: 5 to 6 foot trees, 50 cents each.

\section{HANSEN HYBRID PLUMS}

If you want an abundance of delicious plums be sure to plant a few Hansen Hybrids. They come into bearing young and are extremely productive.

Sapa-Fine for eating from the tree or for preserving. Skin thin; color purple, turning ver. dark when ripe. Hangs well to tree after ripening.
Hanska-Bright red, with blue bloom. Good for preserving and one of the best plums for eating from the tree.

PRICE of Hansen Hybrids, Sapa or Hanska: 5 to 6 foot trees, 75 cents each.

\section{CHERRIES}

' 1 'he Cherry is one of the most attractive of our fruits. No farm is too large (ir city lot too small to have at least one cherry tree. The Cherry is a prolific and almost annual bearer, and will bring large returns for a small outlay.

Early Richmond-Dark red; juicy and productive.
Large Montmorency-Large; red; valuable and productive.

PRICES of above Cherry trees, 4 to 5 feet: 35 cents each. 